\title{
Chapter 1 \\ The Importance, History, and Impact of Academic Entrepreneurship
}

\section{Learning Objectives}

- To understand the role and mission of universities past, present and future.

- To understand the nature of academic entrepreneurship.

- To understand the importance and future of academic entrepreneurship.

\section{Opening Profile - Prabir K. Dutta}

\section{Q1. Submitter Information}

Name of Nominee

University the Nominee is representing Email

Phone number
Prabir K. Dutta

The Ohio State University

dutta.1@osu.edu

6142924532

Professor Dutta is a Distinguished University Professor at The Ohio State University in the Department of Chemistry and Biochemistry. He has published 262 referred manuscripts as an independent investigator, several book chapters, edited two books, is the author of 17 issued patents, 
eight patent applications, and been a mentor for about 100 postdoctoral and graduate research students. The Ohio State University has licensed several of Professor Dutta's sensor inventions to companies, most recent being Spirosure, a startup company in California that has translated Professor Dutta's invention into a breath monitor product for predicting asthma attacks. Professor Dutta has recently founded his own company, Zeo Vation, which is an applied materials company focused on Zeolitic microporous materials with added functionalities for environmental and consumer markets. On the pedagogical side, a significant contribution has been to develop a NSF-supported Ohio-wide effort to alter the curriculum of undergraduates taking chemistry courses with the goal of increasing the number of Science and Engineering graduate in the state of Ohio. The innovation was to introduce research into the laboratory curriculum, and this program has reached tens of thousands of students across Ohio. Professor Dutta is a Fellow of AAAS and National Academy of Inventors.

\section{Q2: The nominee's position when they created the company. Describe the nominee's process with the university as they were creating the company. Be as detailed as possible.}

Professor Dutta was Distinguished University Professor in The Department of Chemistry and Biochemistry at The Ohio State University (OSU) when he co-founded the company ZeoVation in 2016-2017. Over the past decade, Prof. Dutta has been active in patenting research coming from his laboratory. With the help of the Technology Commercialization Office (TCO) at OSU, many of these patents were licensed to companies including Nextech, Ceramatech, Measurement specialties, K\&A Wireless, and Spirosure. Some of these companies have gone on to develop commercial products based on Prof. Dutta's technology. By interacting with these companies, Prof. Dutta gained considerable experience in writing patents, raising funds, IP protection and manufacturing issues with device fabrication and scale-up. In 2016, Dr. Bo Wang, a Ph.D. student in Prof. Dutta's laboratory got interested in commercialization of academic research and took a course in "Entrepreneurship" at OSU.

This course and his interactions with young entrepreneurs motivated Dr. Wang to consider forming a startup company based on his thesis 
research. Prof. Dutta encouraged Dr. Wang to proceed with his startup idea. Dr. Wang got in touch with Rev1, an inventor startup organization in Columbus, which acts as a hub to connect startups with corporate innovators.

Rev1 has a history of working with TCO to develop OSU technologies. Rev1 conducts a quarterly competition to determine which clients they will accept, and Dr. Wang applied for consideration. Prof. Dutta and Dr. Wang also started to develop their business model centering on the use of nano and hierarchical zeolites for consumer applications. OSU also filed patents on the synthesis procedures that Dr. Wang developed for nano and hierarchical zeolites. The initial product development focused on sunscreens and antimicrobials. Rev1 and TCO carried out a customer survey to determine the level of interest in the products proposed by Prof. Dutta and Dr. Wang. Based on the consumer analysis and presentations by Prof. Dutta and Dr. Wang, Rev1 decided to take the startup on as a client. This meant the startup could take advantage of the extensive legal, financial, and management network of Rev1 and OSU. Dr. Wang and Prof. Dutta incorporated the company as ZeoVation Inc.

\section{Q3: Describe the nominee's experience working with the university in} creating the company. What were the challenges? What support did they receive? Be as detailed as possible.

With the startup of ZeoVation, there were three immediate challenges: finalizing negotiations with OSU and Rev1, formalizing a 5-year business plan, and raising seed funding. ZeoVation needed a CEO in place, who had experience in the business. Rev1 and TCO were helpful in finding a CEO, Mr. Steve Jones, who had considerable business experience in both the US and Asia. Mr. Jones negotiated with OSU the patent licensing and with Rev1 regarding ownership. Mr. Jones also negotiated with nearly a dozen seed investors.

These legal negotiations and setting up the final version of the ownership of the company required considerable time, patience and business savvy decisions by Mr. Jones and the legal team.

Q4: What happened to the company the nominee created? Describe in detail where it is now and how is it doing. What is the history of the company? Be as detailed as possible. 
ZeoVation is an advanced material company imparting novel functionality to the zeolite platform to generate consumer products. Early on, ZeoVation set up a website and started selling the nanozeolite and hierarchical zeolite (gram scale) for academic researchers. The goal was to generate a revenue stream that would facilitate product development. ZeoVation also obtained funding from the State of Ohio's commercialization efforts, Rev1 and individual investors. A process engineering company identified the unit operations and carried out an analysis of the requirements of a pilot plant capable of manufacturing the products at the ton level. In addition, funds were spent for developing the sunscreen and antimicrobial formulations. ZeoVation's business model is to interest both small and large companies to evaluate the present products, and then co-develop a product suited to the company requirements. ZeoVation has been successful in setting up relationships with five companies, including materials transfer agreements, and are in discussions with three other companies. The goal is to set up Joint Development Agreements (JDA) with these partners and begin manufacturing at the ton scale with toll manufacturers, based on the current pilot plant specifications. Once the JDAs are in place, ZeoVation will also seek series A financing, expected to occur in 2019. ZeoVation is also writing SBIR/STTR proposals with OSU as a partner. Being able to use OSU facilities for carrying out the base R\&D associated with the products has also been a significant help for ZeoVation.

\section{Introduction}

As is indicated in the profile, academic entrepreneurship which will be viewed in this book as "a member of the university community (faculty, staff, or student) forming a new venture," is a process that is attracting the attention of policymakers, academic institutions, financial institution, economist, as well as the overall population. Questions that have been raised include: Is this the role of a university? Will farming and spinning off ventures in a university erode the intellectual mission of the university? Will the university as well as the economy and society benefit from these activities? How should the proceeds and ownership of this activity be divided? What role should a government or governmental agency play in this activity? 
This chapter addresses these and other aspects of academic entrepreneurship by first addressing the history and role of universities. This is followed by discussing the impact of universities on the economy of the region, country, and world. After presenting the impact of universities, the chapter concludes with a discussion of academic entrepreneurship and an entrepreneurial university.

\section{Origin and History of Universities}

The term university comes from the Latin Universitas Magistrorum et Scholarium meaning a "community of teachers and scholars". The origin of a university as a formal institution was from a medieval Christian setting (Ruegg, 1992). Most of the first universities established had their roots in Christian cathedral schools or monastic schools where monks and nuns taught classes. These date back to the 6th century AD (Riche, 1978). Prior to the 12th century, the intellectual aspects of the culture of Western Europe occurred in monasteries and was mostly concentrated on prayer and performing literacy with only rare instances of investigation and intellectual understanding. The emphasis of the Gregorian Reforms was on canon law and the study of the sacraments resulted in Catholic schools being established mainly to train clergy in canon law and such aspects of administration as logic and disputation for use in theological discussion and preaching and accounting to help enlarge and control the finances of the institution. One figure emerged in the 11th century significantly impacted the transformation of these cathedral schools into the first European universities. Pope Gregory VII issued his 1079 Papal Decree that promoted and regulated these cathedral schools which transformed themselves into the first universities emerging in the 11th century (Ostereich, 1913).

Appropriately, the first university established was in the Holy Roman Empire in the Kingdom of Italy - the University of Bologna which had its charter granted formally in 1158.

Using the traditional definition of a university which is derived from the Latin Universitas Magistrorum et Scholarium meaning a "community of teachers and scholars," the seven (7) oldest universities in continuous operation are indicated in Table 1. Following the University of Bologna 
Table 1. List of oldest universities in continuous operation.

\begin{tabular}{|c|c|c|c|c|}
\hline \multirow[b]{2}{*}{ Year } & \multirow[b]{2}{*}{ University } & \multicolumn{2}{|c|}{ Location } & \multirow[b]{2}{*}{ Notes } \\
\hline & & Original & Current & \\
\hline $\begin{array}{l}1088 \text { (charter } \\
\text { granted 1158) }\end{array}$ & University of Bologna & $\begin{array}{l}\text { Kingdom of Italy, } \\
\text { Holy Roman } \\
\text { Empire }\end{array}$ & $\begin{array}{l}\text { Bologna, } \\
\text { Italy }\end{array}$ & $\begin{array}{l}\text { The oldest university in the world. A university in the sense of a } \\
\text { higher-learning, degree-awarding institute, the word university } \\
\text { (Latin: universitas) having been coined at its foundation. It received, } \\
\text { in 1158, from Emperor Frederick I Barbarossa the "Authentica } \\
\text { habita", which settled the rules, rights and privileges of universities. }\end{array}$ \\
\hline $\begin{array}{l}1134 \text { (charter } \\
\text { granted in } \\
1218)\end{array}$ & $\begin{array}{l}\text { University of } \\
\text { Salamanca }\end{array}$ & Kingdom of León & $\begin{array}{l}\text { Salamanca, } \\
\text { Spain }\end{array}$ & $\begin{array}{l}\text { The oldest university in the Hispanic world. The university claims to } \\
\text { have been founded by Alfonso IX of León in } 1218 \text { (although James } \\
\text { Trager's People's Chronology sets its foundation date as 1134), } \\
\text { making it the third or fourth oldest university in continuous } \\
\text { operation. It was the first European university to receive the title of } \\
\text { "University" as such, which was granted by the King of Castile and } \\
\text { León, Alfonso X, and the Pope in 1254. After being excluded from } \\
\text { the University in } 1852 \text { by the Spanish government, the Faculties of } \\
\text { Theology and Canon Law became the Pontifical University of } \\
\text { Salamanca in 1940. }\end{array}$ \\
\hline $\begin{array}{l}1222 \text { (probably } \\
\text { older) }\end{array}$ & University of Padua & Lombard League & Padua, Italy & Founded by scholars and professors after leaving Bologna. \\
\hline $1224(1258)$ & $\begin{array}{l}\text { University of Naples } \\
\text { Federico II }\end{array}$ & Kingdom of Sicily & Naples, Italy & $\begin{array}{l}\text { The first public university, founded by Frederick II, Emperor of the } \\
\text { Holy Roman Empire. The university moved to Salerno in 1253, and } \\
\text { its return to Naples in } 1258 \text { is sometimes considered as a } \\
\text { refoundation. It is considered to be the oldest public and state } \\
\text { university in the world. }\end{array}$ \\
\hline
\end{tabular}




\begin{tabular}{|c|c|c|c|c|}
\hline $\begin{array}{l}1209 \text { (charter } \\
\text { granted in } \\
1231)\end{array}$ & $\begin{array}{l}\text { University of } \\
\text { Cambridge }\end{array}$ & Kingdom of England & $\begin{array}{l}\text { Cambridge, } \\
\text { United } \\
\text { Kingdom }\end{array}$ & $\begin{array}{l}\text { Founded by scholars leaving Oxford after a dispute caused by the } \\
\text { execution of two scholars in } 1209 \text {. Its royal charter was granted in } \\
\text { 1231. The University takes } 1209 \text { as its official anniversary. Inspired } \\
\text { the establishment of Cambridge, Massachusetts, United States, with } \\
\text { the first college in the United States, Harvard University named } \\
\text { after one of Cambridge University's alumni, John Harvard. }\end{array}$ \\
\hline $\begin{array}{l}\text { 1096-1167 } \\
\text { (charter in } \\
\text { granted 1248) }\end{array}$ & University of Oxford & Kingdom of England & $\begin{array}{l}\text { Oxford, } \\
\text { United } \\
\text { Kingdom }\end{array}$ & $\begin{array}{l}\text { The oldest university in the English-speaking world: Oxford claims its } \\
\text { founding ("..teaching existed ... in some form..") as early as } 1096 \text {, } \\
\text { and not later than } 1167 . \text { Rashdall takes } 1167 \text { as the date when } \\
\text { Oxford became a studium generale. In } 1254 \text {, Pope Innocent IV } \\
\text { granted Oxford a university charter by papal bull ("Querentes in } \\
\text { agro"). Teaching was suspended in } 1209 \text { (due to the town's } \\
\text { execution of two scholars) and in } 1355 \text { (due to the St. Scholastica } \\
\text { Day riot), but was continuous during the English Civil War } \\
\text { (1642-1651), when the University was Royalist. }\end{array}$ \\
\hline 1290 & University of Coimbra & $\begin{array}{c}\text { Kingdom of } \\
\text { Portugal }\end{array}$ & $\begin{array}{l}\text { Coimbra, } \\
\text { Portugal }\end{array}$ & $\begin{array}{l}\text { It began its existence in Lisbon with the name Studium Generale } \\
\text { (Estudo Geral). Scientiae thesaurus mirabilis ("the admirable } \\
\text { treasure of knowledge"), the royal charter announcing the institution } \\
\text { of the University, was dated } 1 \text { March } 1290 \text {, although efforts had } \\
\text { been made since at least } 1288 \text { to create this first university in } \\
\text { Portugal. Papal confirmation was also given in } 1290 \text { (on } 9 \text { August of } \\
\text { that year), during the papacy of Pope Nicholas IV. }\end{array}$ \\
\hline 1290 & University of Macerata & Papal States & $\begin{array}{l}\text { Macerata, } \\
\text { Italy }\end{array}$ & $\begin{array}{l}\text { Founded in } 1290 \text {, possibly as a private law school rather than a } \\
\text { university. Unknown whether this was in continuous operation, but } \\
\text { there is evidence for a school (without degree awarding powers) in } \\
\text { 1518. After petitions from the commune to the Pope from 1534, bull } \\
\text { establishing a studium generale issued in } 1540 \text {. }\end{array}$ \\
\hline
\end{tabular}

Source: Adapted from Wikipedia. 
(chartered in 1,158), in terms of date of charter, are the University of Salamanca (chartered in 1218), the University of Padua (chartered in 1222), the University of Naples (chartered in 1224), the University of Cambridge (chartered in 1231), the University of Oxford (chartered in 1248), the University of Coimbra (chartered in 1290), and the University of Macerata (chartered in 1290). Each of these universities were already having activities before being chartered. Some notes on each university are also indicated in Table 1.

\section{Impact of universities on economics}

While each and every university has some impact on the economics of the area where it is located in terms of jobs, supplying companies, cultural and sporting events, and housing; two such universities in the United States will be discussed - Massachusetts Institute of Technology (MIT) and Stanford. ${ }^{1}$

\section{Massachusetts Institute of Technology}

MIT has a rich history in entrepreneurship and innovation which has a substantial impact on the economies of the region, the United States, and the world. In a report released in 2015, it was estimated that the more than 30,200 active companies of the entrepreneurial alumni employed more than 4.6 million people and had annual revenues of over $\$ 1.9$ trillion which is more than the gross domestic product (GDP) of the 10th largest economy in the world. This is a substantial increase from the reported numbers of 2006 - 25,800 active companies worldwide employing 3.3 million people. The companies were founded in several sectors: biotechnology and medical devices, computer hardware, energy, engineering, manufacturing, and software. The software was the largest sector representing $18 \%$ of all alumni companies. A survey of alumni found that:

\footnotetext{
${ }^{1}$ For more details on the economic impact of each university go to the website of each university: MIT — http://news.mit.edu/2015/report-entrepreneurial-impact-1209; Stanford University — https://engineering.stanford.edu/news/alumni-survey-measures-stanford-seconomic-impact.
} 
- $80 \%$ of alumni-founded companies survived 5 or more years and $70 \%$ survived 10 years.

- $25 \%$ of the alumni have founded companies with $40 \%$ being serial (repeat) entrepreneurs.

- $11 \%$ of alumni-founded companies within 5 years of graduation in the 2010 s compared to $8 \%$ who founded companies in the 1990 s versus $4 \%$ in the 1960s. MIT was instrumental in developing a corridor of entrepreneurial firms labeled Route 128.

\section{Stanford University}

Similarly, Stanford University has had a significant economic impact on its region by incubating ideas, educating entrepreneurs, and fostering breakthrough innovations. A report based on a 2011 survey indicated that more than 39,000 active companies have their roots in Stanford University. The \$2.9 trillion revenue of these companies is more than the GDP of the 10th largest economy in the world, similar to MIT. These companies created an estimated 5.4 million jobs. Other interesting results of the survey include the following:

- $25 \%$ of the faculty respondents reported founding or incorporating a company.

- $55 \%$ of the respondents who became entrepreneurs in the last decade chose to study at Stanford due to its entrepreneurial environment.

- 18,000 firms created by Stanford alumni formed companies in California. These companies had revenues of $\$ 1.27$ trillion and employed more than 3 million individuals.

- $25 \%$ of the entrepreneurs located their companies within 20 miles and $39 \%$ within 60 miles of Stanford. Stanford University was indeed the driving force behind the formation of what is labeled Silicon Valley.

\section{The Entrepreneurial University}

Recognized research universities have at least one characteristic in common - a commitment to the independent inquiry of their scholars to push the frontiers of the knowledge of their discipline and pass this 
knowledge on to successive generations. Circumstances today require that a university, in addition, needs to be managed more strategically using modern concepts and techniques to emerge as a new, organization and assist in the development of the economics in the region, country, and world in agriculture, industrial, and service sectors through innovation and problem-solving.

The goal to understanding this new role and purpose of higher education institutions (universities) has taken many directions since the musing of Newman about "the idea of a university" (Newman, 1852). This purpose is now centered on the civic and economic roles of universities. This new focus (in addition to continuing the focus on education and research) is best captured by the term "entrepreneurial university". The origin of this term is found in the book Academic Capitalism by Slaughter and Leslie (1997). The authors feel that an entrepreneurial university develops activity and energy to support the motion of enterprise. This means there will be risk taking in initiating new practices that have outcomes that may not be positive. These universities will be significant players on their defined dimensions allowing entrepreneurship as a process and outcome to flourish. This new form of a university will attract students such as was indicated in the case of Stanford University previously described. The result will be seen in outcomes in two areas: (1) academic entrepreneurship which focuses on the commercialization of knowledge and research findings (Klofsen and Jones-Evans, 2000) and (2) entrepreneurship education which links this third focus to the teaching mission (Gibb and Hannonn, 2006).

Since businesses, governments, societies, and universities are quite different throughout the world this task of creating an entrepreneurial university that does research, teaching, and commercialization is not an easy task and will take a wide variety of forms. Despite an increase in the number of books and articles on the topic, nothing definitive has been articulated. One area that needs significant attention is the institutional aspect of the third mission university problem. The entrepreneurial university as an institution is shaped by the environment in which it operates while it in turn is transforming this very environment.

While assisting in the development of more entrepreneurial universities, even government laws and incentives have come up short (for a 
discussion of thesis, see Lockett et al., 2005). The Bayh-Dole Act of 1980 attempted to accelerate the diffusion of research and new technology by university and even more by several laboratories in the United States. Technology transfer offices (TTOs) were created in most universities to assist in this process by licensing the technology to organizations; mainly businesses outside the university. An annual "Technology Transfer" conference occurs yearly where individuals meet and present ideas and papers on the topic. It is estimated that over $\$ 10$ trillion of technology lies hallow in various university settings. Leaders agree the revenue obtained, companies formed, and regional impact (Silicon Valley and Route 128) such as Stanford and MIT have moved towards but have not obtained the results of an entrepreneurial university.

Money has not been able to significantly affect this transformation process. Large multimillion-dollar grants from the Kauffman Foundation to several universities in the United States have not produced any significant results.

Attempts outside the United States have been equally frustrating. In the United Kingdom starting around 1988, British business leaders collaborated with the Thatcher government to build an enterprise culture in higher level education. Legislation such as the Science Enterprise Challenge, the Higher Education Enterprise Fund, and the University Challenge were enacted to: stimulate the commercialization of university-based research; develop public-private partnerships; and to create more innovation in small firms (Rasmussen et al., 2014). Even with this cooperative effort and legislation, movement to add the third dimension of commercialization of research and teaching as exemplified in such universities as Cambridge; no entrepreneurial university emerged.

Similarly, in Norway, universities have attempted to incorporate this third dimension of commercialization as well. The ownership of intellectual property previous assigned to the university research scholar was transferred to universities starting in 2003 (Wigren-Kristolersan et al., 2011). ${ }^{11}$ In Sweden, the law of university teacher's exemption, allow researchers to retain full rights to their discoveries without having some percentage go to their institution — the University — remains 
(Lockett et al., 2014). Yet, one cannot describe the universities of the Chalmers University of Technology, The Arctic University of Norway, or Stavanger as being entrepreneurial universities. And, the list of countries, societies, economies, and faculty to establish an entrepreneurial university goes on. Given the complexity of the challenge, it is difficult to imagine an entrepreneurial university emerging in the near future if ever.

\section{Academic Entrepreneurship}

As was previously discussed, the substantial increase in the commercialization of science and technology has become of more interest in the last 10 years. The process of doing this by creating university spin-offs instead of the more traditional technology transfer has become even more important for universities throughout the world.

This new emphasis on business spin-offs is far different from the era when universities first established TTOs in the 1980s (Hisrich et al., 2017). Up until the advent of entrepreneurship courses and programs and entrepreneurship itself as an academic discipline which is often cited as the first Babson Research Conference in 1981; the focus was patenting and licensing. Only recently has academic entrepreneurship and involvement in the economic aspects of the region became the third aspect of a university mission. This has only occurred at a few universities.

Entrepreneurship can be thought of as the ability to create something new of value by taking the necessary risks involved. The individual(s) doing this has an entrepreneurial mindset which involves "the ability to rapidly sense, act, and mobilize even under uncertain conditions" (Tijssen, 2006). With this entrepreneurial mindset, two entrepreneurial functions occur: identification and exploitation. These two functions vary in terms of the type of knowledge transferred, the risks involved, and the complexity of the activity. There are differences between university entrepreneurial activities based on the transfer of knowledge created by consulting or contract research, the transfer of technology through patents or licensing, and the transfer of products/services through spin-offs. Academic entrepreneurship in this book focuses on the transfer of products/services through spins or the exploitation point of entrepreneurship. More specifically academic entrepreneurship is "the formation of a new enterprise by 
someone employed by (faculty, research, or staff) or attending (student) the university". The academic entrepreneur goes through the commercialization process of idea generation, commercialization decision, prototype development, determination of technical and commercial validity, forming the founding team, determining the strategy and commercialization process, obtaining the needed capital, and launching the venture.

The academic entrepreneur can be: (1) an individual faculty member, researchers, staff, or student; (2) any of these partnering with an experienced entrepreneur; (3) any of these partnering with a business school professor or student; (4) any one of these partnering with any of the others such as faculty member partnering with a Ph.D. or postdoctoral student.

What are the usual problems encountered in having an abundance of academic entrepreneurship occur in the university setting? The first problem is the reward system by the university. There is a need for a university interested in creating an environment supportive of academic entrepreneurship to adopt promotion, tenure, and overall reward system to include commercialization activities. The first major university in the United States to reward commercialization in promotion and tenure was Texas A\&M in 2006. Since then other universities have followed this practice. These include: Brigham Young University; George Mason University; New York University; Northern Arizona University; Ohio University; Oregon State University; University of Arizona; University of Maryland; University of North Carolina at Greensboro; University of Nebraska; University of Texas Health Science Center, Houston; Utah State University; and Wake Forest University, Health Sciences. The more commercialization can be an input into the reward system of a university the more academic entrepreneurship will occur by individuals particularly faculty and researchers employed there.

The second problem occurs when administrators of the university (presidents, vice presidents, deans, and even technology transfer officers) have little understanding and even less appropriate skills to develop and support commercialization strategies. Most upper-level university positions at the Vice President or President level are filled by individuals well versed in the arts and/or sciences with little or no knowledge of business and commercialization. And TTOs are challenged by a dual agency that does both licensing and spin-offs transfer of technology when previously 
the single focus was licensing. The more information and training that can be provided; the more academic entrepreneurship will occur when these groups are not only familiarized with but support the activity.

A third problem is the prospect of increased conflict when outside parties are introduced to the university. University administrators, faculty, researchers, students, and technology transfer officers have different and conflicting objectives and cultures. Their differences are amplified when angels, venture capitalists, and corporations add a further level of conflict. The more understanding that can occur between all these entities are needed for the resources, specifically funding, the more academic entrepreneurship will occur.

A fourth problem occurs in universities that are state-sponsored and those that are unionized. To flourish, academic entrepreneurship requires the opposite environment of control through state government and unions. A new ecosystem at the university needs to be established to encourage and promote academic entrepreneurship for the process to flourish and increase at the university level.

A fifth problem involves the amount of creativity that is encouraged and occurs at the university. It has been shown that education often hinders creativity by the courses and test administered rather than to encourage and support it. One story about a young girl in class illustrates this very well. A kindergarten teacher gave the class the assignment of drawing any flower they wanted. One young girl asked the teacher "what type of flower?" The teacher responded, "any flower you want to create." The young girl unsure of the assignment asked again, "what type of flower". The teacher response was "draw a red flower on a green stem." And, of course, the young girl handed her assignment — "a red flower and a green stem." I am sure each of you reading this book can produce numerous examples of the same situation. Creativity needs to be encouraged and supported in a university rather than hindered.

Finally, and perhaps one of the hardest to correct is the resistance to change. Members of the university, as well as the entire university itself, are steeped in tradition and established processes which lead to stagnant teaching and the lack of individuals to accept new ideas that will lead to change. This resistance and inability to change does not encourage or 
support academic entrepreneurship. This resistance needs to be dealt with through carefully selected information dissemination and discussions. In terms of academic entrepreneurship, the use of successful examples of academic entrepreneurship at other universities and the benefits that resulted.

\section{Future}

In spite of these issues, the future of academic entrepreneurship is very bright. Indeed, spin-offs need to be promoted from an institutional perspective either directly from faculty, researchers, staff, and students at the university or indirectly through graduates (alumni) of the university. Typically, the innovation policy of a university focuses on radical innovation with a high rate of uncertainty, risk, and failure. Entrepreneurship policy focuses on stimulating new ventures through innovations at all levels of uniqueness: radical (breakthrough), technological, and ordinary innovations. A new approach is needed to integrate both aspects so academic entrepreneurship can flourish and new venture spin-offs can occur. This may result in different institutional content that provides the framework and resources required to support academic entrepreneurship. Establishing and building a university ecosystem is the focus of the next chapter. The significant areas in entrepreneurship courses and programs, entrepreneurship centers, and university development officers indicate academic entrepreneurship has the opportunity to occur at universities throughout the world.

\section{Summary}

This chapter begins by focusing on the origin and history of universities to set the stage for the universities impact on the economies of the regional, national, and world economy. Two universities in the United States are discussed - MIT and Stanford University. Following a presentation of the entrepreneurial university is a discussion of academic entrepreneurship. The Chapter concludes with ideas for the future policy changes needed to occur in a university setting. 


\section{Selected Readings}

(1) Siegel, D. S. and Wright, M. (2015). Academic entrepreneurship: Time for a rethink? British Journal of Management, 26(4), 582-595.

Academic entrepreneurship, which refers to efforts undertaken by universities to promote commercialization on campus and in surrounding regions of the university has changed dramatically in recent years. Two key consequences are more stakeholders have become involved in academic entrepreneurship and universities have become more "strategic" in their approach to this activity. The authors assert the time is ripe to rethink academic entrepreneurship. Specifically, theoretical and empirical research on academic entrepreneurship needs to take account of these changes, so as to improve the rigor and relevance of future studies on this topic. We outline a framework and provide examples of key research questions that need to be addressed to broaden the understanding of academic entrepreneurship.

(2) Wright, M., Siegel, D. S. and Mustar, P. (2017). An emerging ecosystem for student start-ups. The Journal of Technology Transfer, 42(4), 909-922.

New initiatives in student entrepreneurship programs are moving rapidly beyond traditional classroom teaching to experiential learning, which is associated with improved employment outcomes for students [Gosen and Washbush (2004). Simul Gaming, 35, 270-293]. Unfortunately, we lack a framework to understand the ecosystem required to enable our students to launch successful startups. In this article, we develop such a framework. The elements of this framework include university mechanisms to facilitate student entrepreneurship, along with a continuum of involvement from pre-accelerators through to accelerators; the involvement of a variety of entrepreneurs, support actors and investors; the particular nature of the university environment and the external context; and their evolution over time. We also consider the important issue of funding mechanisms.

(3) Hayter, C. S., Lubynsky, R. and Maroulis, S. (2017). Who is the academic entrepreneur? The role of graduate students in the development 
of university spinoffs. The Journal of Technology Transfer, 42(6), 1237-1254.

Academic entrepreneurship, the establishment of new companies based on technologies derived from university research, is a well-recognized driver of regional and national economic development. For more than a decade, scholars have conceptualized individual university faculty as the primary agents of academic entrepreneurship. Recent research suggests that graduate students also play a critical role in the establishment and early development of university spinoff companies, but the nature of their involvement through the entrepreneurial process is not yet fully understood. Employing a case study approach, this paper investigates the role of graduate students in early-stage university spinoff companies from the MIT. We find that graduate students play role similar to that of individual faculty entrepreneurs in university spinoffs, both in terms of making the initial establishment decision and in reconfiguring the organization for marketable technology development. We also find that student entrepreneurs face unique challenges involving conflicts with faculty advisors and other students.

(4) Astebro, T. B., Braguinsky, S., Braunerhjelm, P. and Broström, A. (2016). Academic Entrepreneurship: Bayh-Dole versus the 'Professor's Privilege'. HEC Paris Research Paper No. SPE-2015-1118.

This article explores whether the Bayh-Dole intellectual property regime is associated with more, and more valuable academic entrepreneurship than the "Professor's Privilege" regime. Using data on US STEM Ph.D.'s becoming entrepreneurs during 1993-2006 and similar data from Sweden we present evidence showing that in both countries the entry rate into entrepreneurship is lower for those originating from academia than for those originating from non-university employment, and that the relative rate of academic entrepreneurship is slightly lower in the US than in Sweden. We also find that the mean economic gains for becoming an entrepreneur is negative, both for Ph.D.'s originating from academia and non-university alike in both countries. Further analysis indicates that in both countries there is selection from the bottom of the ability distribution among academics. The results suggest that policies aimed at 
screening entrepreneurial decisions by younger, tenure-track academics may be more effective than general incentives to increase academic entrepreneurship.

\section{References}

Gibb, A. and Hannonn, P. (2006). Towards the entrepreneurial university. International Journal of Entrepreneurship Education, 4(1), 73-110.

Hisrich, R. D., Peters, M. D. and Shepherd, D. A. (2017). Entrepreneurship, 10th edition. New York: McGraw-Hill Education, p. 11.

Klofsen, M. and Jones-Evans, D. (2000). Company academic entrepreneurship in Europe: The case of Sweden and Ireland. Small Business Economics, 14(4), 299-309.

Lockett, A., Siegel, D., Wright, M. and Ensley, M. D. (2005). The creation of spin-off firms of public-research institutions: Managerial and policy implications. Research Policy, 4, 981-993.

Lockett, A., Wright, M. and Wild, A. (2014). The institutionalization of third stream activities in U.K. higher education: The role of discourse and metrics. British Journal of Management, DOI: 10.1111/1467-8551.12069.

Newman (1852). The Idea of an University. London: Longmans, Green and Company.

Ostereich, T. (1913). Pope St. Gregory. In: Herbermann, C. (ed.), Catholic Encyclopedia. New York: Robert Appleton Company.

Rasmussen, E., Mosey, S. and Wright, M. (2014). The influence of university departments on the evaluation of entrepreneurial competence in spin-off ventures. Research Policy, 43, 92-106.

Riche, P. (1978). Education and Culture in the Barbarian West From the Sixth through Eighth Century. Columbia: University of South Carolina Press, pp. 126-127 and 292-298.

Ruegg, W. (1992). Forward: The University as a European Institution. In: A History of the University in Europe, Vol.1: Universities in the Middle Ages. London: Cambridge University Press, pp. xix-xx.

Slaughter, S. and Leslie, L. L. (1997). Academic Capitalism: Politics, Policies, and the Entrepreneurial University. Baltimore: John Hopkins University Press.

Tijssen, R. J. (2006). Universities and industrially relevant science: Toward measurement models and indicators of entrepreneurial orientation. Research Policy, 35(10), 1569-1585. 
Wigren-Kristolersan, C., Gabrielson, J. and Kitagawa, F. (2011). Mind the gap and bridge the gap: Research excellence and the diffusion of academic knowledge in Sweden. Science and Public Policy, 38(6), 481-492. 